This item was submitted to Loughborough's Research Repository by the author.

Items in Figshare are protected by copyright, with all rights reserved, unless otherwise indicated.

\title{
The populist surge in post-democratic times: Theoretical and political challenges
}

\section{PLEASE CITE THE PUBLISHED VERSION}

https://doi.org/10.1111/1467-923X.12317

\section{PUBLISHER}

John Wiley \& Sons Ltd @ The Author and The Political Quarterly Publishing Co. Ltd

\section{VERSION}

AM (Accepted Manuscript)

\section{PUBLISHER STATEMENT}

This work is made available according to the conditions of the Creative Commons Attribution-NonCommercialNoDerivatives 4.0 International (CC BY-NC-ND 4.0) licence. Full details of this licence are available at: https://creativecommons.org/licenses/by-nc-nd/4.0/

\section{LICENCE}

CC BY-NC-ND 4.0

\section{REPOSITORY RECORD}

Katsampekis, Giorgos. 2019. "The Populist Surge in Post-democratic Times: Theoretical and Political Challenges". figshare. https://hdl.handle.net/2134/28478. 
GIORGOS KATSAMBEKIS

\section{The populist surge in post-democratic times. Theoretical and} political challenges

Introduction: the 'great danger' of populism

Populism has often been described as the ultimate threat for Europe. In fact, it is not very long since the former EU President, Herman van Rompuy called populism 'the greatest danger for Europe' (FAZ, 9 April 2010). In a similar tone, Jean-Claude Juncker recently issued a warning that the EU is in a battle with 'galloping populism' (Times, 14 September 2016). What about the media? Populism 'is a real threat to mainstream democracy,' noted Anthony Painter in the New Statesman (22 March 2013). 'Populism is tearing Europe apart,' read the editorial of La Razón, right after the British referendum (25 June 2016). 'The populists are on the loose, [...] dragging Western Europe towards its downfall,' stressed Der Spiegel around the same days (26 June 2016). Similar headlines and statements appear very often in newspapers across Europe. And while academics usually adopt more 'neutral' approaches to the phenomenon, avoiding axiological readings and moralist denunciations, it is not rare to encounter renowned researchers that are a priori dismissive of populism, interpreting it as a fundamentally anti-pluralist and anti-democratic phenomenon, an imminent danger to be dealt with. ${ }^{1}$

My aim in this article is to offer a brief yet comprehensive overview of the relevant discussion in a bid to problematize the supposed 'imminent threat' of populism in 
light of recent developments within the political systems and societies of established democracies, especially under conditions of economic and political crisis.

\section{Populists on the rise, then and now}

During the recent years of crisis and austerity there has been a significant rise of populist parties in Europe, with some of them winning elections and disturbing previously established hegemonies, causing significant realignments and thus changing the rules of the (political) game. The same can be said for the US, where we have seen both populist social movements and politicians rise to prominence, posing serious challenges to the established political elites. In this sense, the 'alarming' populist challenge, that is so often discussed in the public sphere, has a 'real' concrete base, as populists of various shapes and colours are indeed gaining ground in Europe and across the world. Interestingly, this 'populist surge' has brought renewed intensity to the debate around the crisis of democracy itself and the capacity of existing institutions to express and empower citizens, upholding democracy's promise for popular sovereignty ('power to the people!'). If the people are turning to populist challengers and outsiders, who seem overly radical, or even 'extremist,' then something must be wrong with our democratic-representational systems; something is not working in the representational bond and relation between the governed and the governors, common citizens and the political elites. This, at least, seems to be a common suggestion on the lips of politicians, pundits and academics.

On the other hand, to put things in perspective, one might say that this discussion is not particularly new. Europe has found itself debating the supposedly overwhelming and unstoppable 'rise of populism' many times within the past decades, especially 
since the mid-1980s and the first electoral breakthrough of Jean-Marie Le Pen and the Front National (FN), in France. ${ }^{2}$ During the 1990s and the early 2000s, the so-called 'populist radical right' had its first pan-European breakthrough, with figures like Jörg Haider, Pim Fortuyn, Geert Wilders, and others, joining the spotlight. ${ }^{3}$ And there are numerous other examples of more or less known (alleged) populists that have made significant electoral gains around the same period.

Today, the various populists at the Right of the political spectrum appear to have consolidated their position. The 'renewed' FN under Marine Le Pen poses as a viable contender of power in France, the Finns Party in Finland are participating in a coalition government, holding significant cabinets, the Freedom Party's (FPÖ) candidate, Norbert Hofer was only narrowly defeated in the Austrian presidential election of April 2016 and appears very likely to win in the re-run of the election (in December 2016), while Fidesz and Viktor Orbán's hegemony in Hungary seems rather unchallenged. One might add the victory of the 'Exit' camp in the British referendum, where right-wing (populist) politicians like Nigel Farage, Boris Johnson and Michael Gove played a key role, but also the significant gains of the Alternative for Germany (AfD) as reflected in the result of recent local elections in Germany.

But it is no longer just the rightist populists that are doing well. Under the shadow of the 'Great Recession,' the picture has evolved and we have now witnessed a new surge, which is characterised by the emergence of populist parties that belong to the Left or the Radical Left. The austerity-hit European periphery, and especially the South, has been at the forefront of this new trend. Political parties like SYRIZA in Greece and Podemos in Spain $^{4}$ rode the waves of massive grassroots anti-austerity 
movements and significantly expanded their electoral support, triggering major political re-alignments in their countries and sending shivers throughout Europe. SYRIZA is now nearing two years in government (having won two general elections and a referendum after January 2015), while Podemos participated in intense negotiations to support a government under the Socialists after the national election of December 2015, and has since been established as a major player in the Spanish political system.

In this context, various populist forces have entered government across Europe, or appear as viable contenders of power, while others have established themselves as the main opposition or have managed to win referendums. In other words, they are political actors to be taken seriously, and can no longer be seen as just 'flash parties,' or 'episodic' phenomena that will soon disappear, leaving 'mainstream' parties in peace. But is this good or bad for democracy? And what are the prospects of populism from now on, in a Europe that has found itself entangled in yet another major crisis, the refugee crisis, and along with it new national isolationisms and rising xenophobia?

\section{What is populism?}

To start dealing with such questions we first have to offer a brief yet comprehensive definition of populism. I'll draw here on the emerging consensus around discursive or 'ideational' approaches to the phenomenon, in order to stress some key characteristics on which most scholars seem to agree on. ${ }^{5}$

First of all, populism seems to always entail the discursive construction and interpellation of 'the people' as a collective subject and key actor of social change. 
'The people,' in its various names and guises ('the many,' the 'non-privileged,' 'the 99\%') are called upon as the only ones that can legitimise democratic decision making; as the subject of social change and radical subversion; the ones that, in the final instance, legitimise democratic polity itself. This central position of 'the people' alone, however, is not enough, as most democratic discourses of modern times involve calls upon the people. The populists just seem to be more vocal and emotionally intense about it.

The second key characteristic of populism is its sharp antagonistic worldview: the representation of society as ultimately divided between 'the people' and the 'establishment' (the 'underdog' vs. the 'elite,' the marginalised many vs. the privileged few). Populists are placed on the side of 'the people,' pledging to serve the popular will and reinforce popular sovereignty, accountability and participation, making the political process more open and accountable to popular demands and grievances against power holders and 'oligarchs.'

These two are the core elements of populism that one finds in most scholarly works, like the one of Ernesto Laclau, who has offered one of the most prominent theorizations of populism already from the late $1970 \mathrm{~s},{ }^{6}$ but also in the work of most discourse-oriented scholars. ${ }^{7}$ Laclau understands populism as a specific type of political discourse, a 'logic' which attributes to 'the people' a protagonist position, while challenging at the same time a given power structure. He has thus stressed both the centrality of antagonism in this specific way of doing politics, as well as the role of representation; invocations of the people as well as the construction of antagonistic schemas manifest primarily on the discursive/symbolic level. Laclau has also stressed 
that the concepts 'people' and 'establishment' are empty signifiers, which means that they can take on different meanings depending on the speaker and the context in which they are articulated.

In this sense, populist movements and parties call upon various groups of individuals in order to link and mobilise them against a perceived 'enemy' that is somehow opposing their well-being, undermining their economic and social status, or even threatening their existence. This formal understanding of populism gives us a precise illustration of its political logic - the way in which it typically operates, articulating various discursive elements toward forming a political message and strategy -, which is useful in identifying populist actors, but it does not tell us much regarding the content of populist politics; its ideological, economic, cultural, institutional, or other aspects.

\section{From populism's form to populism's content}

Indeed, populism's contents may significantly vary, depending on the ideology to which it is attached, as well as the socio-economic and historical environment in which it emerges and develops. This explains the fact that we have historically witnessed so many different forms of populist articulations: populisms that favoured statist economic programmes (Hugo Chávez in Venezuela, PASOK in the 1970s1980s Greece) and others that were free-market oriented (Alberto Fujimori in Peru, the Danish and Norwegian Progress Parties); populisms that emerged from the grassroots (the Populist movement in the US of the late $19^{\text {th }}$ century, the Spanish indignados) and populisms that were concentrated on charismatic leaders and strict top-down hierarchies (Juan Perón in Argentina, the Le Pens in France), populisms that 
articulated demands for democratic expansion and social inclusion (Evo Morales in Bolivia, Podemos in Spain) and populisms that defended authoritarian logics and social or ethnic exclusion (Viktor Orbán in Hungary, the FPÖ in Austria); we have also witnesses populisms that led waves of democratisation to gradually lean towards authoritarian paths (Rafael Correa in Ecuador). This highlights not only the 'chameleonic' nature and malleability of populism, ${ }^{8}$ but also the fact that it is practically impossible and methodologically wrong to adopt a firm axiological position vis-à-vis populism tout court, as if it were something good or bad, reactionary or progressive, democratic or anti-democratic. Whether we like it or not, it has been and it can be all of that, depending on the actor that incarnates it and the context in which it manifests.

Therefore, developing a critical and informed opinion regarding 'actually existing' populist movements and parties is absolutely necessary. And there are indeed ways in which we can approach such phenomena, starting with the way in which the populist discursive 'form' is filled with various (ideological, programmatic, cultural, moral, etc.) 'contents.'

In practice, the way in which populists (and non-populist actors) speak about 'the people,' can significantly vary, as others consider the people to be a mono-ethnic community bound by relations of common culture, language or blood, and others might see it as a political community, plural and heterogeneous, bound only by a sense of common fate and commitment to a shared set of values. Moreover, the way in which the antagonism itself with the 'enemy' is signified, can also acquire different contents and directions: in some cases, an unresponsive 'elite' can be blamed for its 
economic injustices and corruption, or it can be castigated for nurturing hidden plans and conspiracies of 'ethnic cleansing,' allowing invading 'others' to 'take over' the country, in others.

Such contingent ideological articulations, once crystallised, will determine the specific character of a given populist mobilisation and thus its significance for the development of a democratic society. In a nutshell: It is not the same rallying a plural people around demands for equal social and political rights and against an unresponsive political elite, with rallying an ethnically 'pure' people against its cultural/ethnic 'others' (immigrants) and around demands that put 'natives' first. Thus, it is only after we scrutinise and carefully assess each case (its ideology, historicity, etc.) that we can develop a critical position that is meaningful and productive in terms of scientific inquiry and also democratic debate. And it is exactly the task of contemporary social scientists to develop such theoretically informed and cautious empirical analyses of populist experiences, following the example of recent works that illustrate both theoretical depth and broad comparative scope. ${ }^{9}$

\section{Left-wing vs. right-wing populisms}

It should have become clear then, up to this point, that it is exactly the specific ideology behind targeting an 'elite' and calling upon a 'people' that defines a populist movement's essence and orientation.

Let me make this rather normative position more concrete and empirically grounded, by focusing on the way in which 'the people' is constructed within the context of leftwing populist discourses in today's Europe. The two most prominent such examples, 
despite their differences, are the ones of SYRIZA and Podemos. Those parties construct 'the people' as a pluralist and heterogeneous collective subject that can include different social classes, ethnicities, religions and sexual orientations, while they also emphasise the need to re-incorporate and represent the marginalised, the lower-classes or excluded sectors of society. In this sense, left-wing populism in today's Europe seems more egalitarian and inclusionary, building its public appeal around issues that concern the socio-economic sphere. As such, it is similar to the Latin American populist-left experience, as exemplified by leaders like Evo Morales, whom has focused a lot on giving voice to the marginalised or excluded sectors of society.

Now, if we move towards the Right of the political spectrum, we will find a quite different conception of 'the people.' For example, the FN in France, or the FPÖ in Austria, as well as other populist radical right parties, all seem to favour a strictly ethnic (even racial) understanding of the people, portrayed as a homogeneous organic community, opposing at the same time minorities (religious, ethnic, etc.), and expressing xenophobic, racist or homophobic views. In this sense, such parties tend to be exclusionary and regressive, connecting the well-being of the 'native' people to the exclusion of alien 'others' and with the restriction of the latter's rights and freedoms.

Such diverging conceptions of the collective subject and of its 'enemy' can have serious policy implications. Take for example the ongoing refugee crisis in Europe and the different ways in which populist leaders have dealt with it. Maybe the most telling contradiction is the one between Greek Prime Minister Alexis Tsipras and Hungarian Prime Minister, Viktor Orbán. The first one has repeatedly stressed the 
need to express solidarity towards the refugees and immigrants, and to welcome them in European societies, while the later has done everything in his capacity to exclude refugees and immigrants, portraying them as threats and potential enemies, as agents of 'islamisation' and 'a danger to the Christian traditions of Europe.' This is not mere rhetoric, since the former's stance is connected to tolerance and integration within a pluralist society, while the latter's nurtures nationalism, chauvinism and exclusion.

It should also seem rather obvious that significant differences can be traced in the ways in which the various populists construct the image of the 'enemy.' Again, in discourses such as the ones of Podemos, the Dutch Socialist Party (SP) and other leftist populist parties, the 'establishment' that is attacked is mostly defined in socioeconomic terms, as a nexus of neoliberal political, economic and media elites, both domestic and international, that favour the interests of the 'few' against the interests of the 'many.' Moving to the right, we see that in the case of the FN or the Dutch Party for Freedom (PVV) and others, the 'elites' (sometimes depicted as 'puppets of the EU superstate') are considered primarily as guilty for letting 'foreigners' take over the country, as irresponsible in not protecting the homogeneity and security of the nation, or even for actively conspiring against it. Thus divisions here are not so much understood in socio-economic terms (although such an agenda is all the more emphasised in the discourse of the FN), but more in cultural and ethnic terms, attacking vulnerable 'others' and minorities that are being targeted for their religion, ethnic origin or sexual orientation.

Lastly, it is crucial to stress that the ongoing research has observed that inclusive, egalitarian and/or pluralist populist parties and initiatives (usually left-leaning) tend to 
be more internationalist and generally rather positive regarding European integration (despite often criticizing the EU in its current form), whereas exclusive and identitarian ones (usually right-leaning) seem to advocate a 'Europe of strong nation states,' or even dismiss the very idea of European integration in general, moving from euro-scepticism to a firm anti-European position.

\section{Identity formation, incorporation, representation}

In this context, I believe that it is wrong - methodologically and politically - to denounce populism tout court as a pathological and anti-democratic form of politics. Indeed, it might be better to understand it as a way - among many others - to appeal to groups of people, even to national audiences, in order to mobilise them against named opponents and at the same time a way to offer some kind of incorporation. Now, this second aspect has not been investigated as much as it should and it needs clarification and discussion.

This populist incorporation can be exclusive and identitarian ('you're one of us, as long as we share the same ethnic origins'), or it can be an inclusive and pluralist one ('you're one of us regardless ethnicity, religion, etc., as long as we stand together against the neoliberal elite'). Admittedly, this is a rather simplified representation of possible articulations, based on the two broader categories of populism that seem to crystallise in Europe, while it is still possible to encounter 'hybrid' cases, that escape the classifications left/right, inclusive/exclusive, monist/pluralist. Such is probably the case of Beppe Grillo's Five Star Movement (M5S) in Italy. It is not a coincidence that commentators and analysts have struggled with classifying the M5S on the left-right 
axis, while Grillo himself has famously stated that his party in neither left nor right, but 'proudly populist'.

The M5S, which rose as part of widespread anti-austerity and anti-establishment protest in the Italy of 2009, has put forth demands for direct and participatory democracy and expanded forms of welfare, focusing on a basic guaranteed income, while taking a firm stance against political corruption. It has also put high in its agenda a series of environmental issues. In this context, it seems to present affinities with left-wing and progressive populisms in Europe and beyond. However, the M5S has established an overwhelmingly personalistic leadership and a centralized structure, leaving little room for internal democracy, transparency and accountability, while it has often criticised trade unions (especially the left-oriented ones). Moreover, the party has sparked controversy when joining the Europe of Freedom and Direct Democracy political group in the European Parliament, which is led by the hardEurosceptic and nationalist UK Independence Party (UKIP). Lastly, Grillo himself has provoked outrage with racist or even anti-Semitic comments, leading some commentators to place him more on the right of the political spectrum. The M5S is not the only 'hybrid' populist case worth lingering on, but it is surely one of the most interesting and analytically challenging ones among the emergent populist parties and it is very telling regarding the ambiguities and paradoxes that penetrate the populist phenomenon in general.

In any case, the function of incorporation, in its various forms, tells us something crucial regarding the conditions of emergence and probable success of a populist project. As many theorists have stressed, populism needs some notion of 'crisis' to 
flourish. But 'crisis' is too vague of a concept to capture the specificity of a sociopolitical environment which favours populist actors. In this respect, Kenneth Roberts has rightly re-situated the discussion on the plane of political representation, linking populist ruptures to specific types of crisis of representation. ${ }^{10}$ One of the scenarios of such crises, that he suggests, is the situation where a political system is characterised by lack of responsiveness or accountability. In this case, while democratic institutions formally work, the rule of law is respected, liberties are secured and parties can freely compete in elections, citizens are left with a feeling of lacking alternatives or of not being heard.

This is due to the fact that - as we have seen in many European countries mainstream parties that dominate the political scene have programmatically converged to such an extent, that it does not really make a difference to vote for one or the other. The 'grand coalitions' in Germany, the 'Proporz' system in Austria, as well as the technocratic governments of Papademos and Monti, in Greece and Italy, provide good examples of such systems of 'post-political consensus' - or even 'forced consensus' -, systems that look rather 'postdemocratic' than actually democratic. ${ }^{11}$ What is more, citizens in Europe have often witnessed the imposition of policies sharply opposed to their mandate, due to external pressures and constraints or even political blackmail. Such is the case, one might say, of the Greek referendum of July 2015 where, despite the people's clear decision to reject a new bailout deal premised on further austerity, such a deal was imposed to the Greek government under the threat of a complete economic collapse and international isolation. One might cynically note here that the EU has a long tradition in ignoring or 'overcoming' referenda decisions that go against the hegemonic agenda, if one recalls what 
happened with French and Dutch referenda on the European Constitution in 2005, or with the Irish referendum on the Treaty of Lisbon on 2008-2009. On top of everything else, voters' disaffection with the established political system has been strengthened by numerous corruption scandals involving the traditional parties in many countries of Europe (e.g. Italy, Greece and Spain).

In such a context, where citizen feel misrepresented or not represented at all, where there are serious doubts about the moral integrity of the political elite and the policies being implemented have little to do with the popular vote, populist politicians and parties can claim to better understand and express the marginalised, frustrated or even infuriated people, against a political system that has become self-serving, unresponsive and alienated. At the same time, discontent can be directly expressed from below, through populist social movements that re-claim 'power to the people,' creating the conditions where 'populism in the streets' can meet with 'populism in the parliament.' It is not a coincidence that recent social movements against austerity in Spain and Greece rallied around the slogan 'you do not represent us' (addressed to traditional parties) and demanded 'true democracy now!'. Crucially, such movements soon found their institutional expression in the party system (indignados in Podemos, aganaktismenoi in SYRIZA, but also Occupy in a series of political figures in the Democrats, but most notably in Bernie Sanders).

\section{Concluding remarks}

Given the widespread feeling that we have entered a critical juncture for democratic institutions, one cannot help but ask: what lies ahead for European and Western democracies? What are the consequences and prospects of populism in today's 
democratic systems? Since populism can appear in varying and contradictory guises, as illustrated above, it is rather hard, maybe impossible to offer a general answer. A rather obvious consequence of populism, though, is the introduction of a more adversarial and confrontational style in the political scene, but this is rather an intrinsic trait of politics itself, and as long as confrontation is not taking violent forms, it cannot be regarded as harmful. In fact, bringing back political confrontation might be a good antidote to the alienation that has been nurtured by post-political consensus; by the widespread sense that all parties are the same, that ideologies and programmes do not matter and that elections rarely make any difference.

Instead of trying to grasp populism's probable consequences, there might be a more important lesson to draw from the success of populist parties and movements and this has to do with the quality of representation itself, as well as the responsiveness of political actors and institutions, bringing into the picture the issues of popular accountability and direct participation.

This is particularly important in today's Europe, where mainstream political forces of centre-left and centre-right seem to have lost their links with civil society, becoming all the more attached to the administrational workings of the state; what the renowned political scientist Peter Mair has described as the 'cartelisation' of political parties, which has spread to the EU itself, making it a remote 'protected sphere,' unaware of people's agonies and grievances. ${ }^{12}$ In one way or another, populist parties are gaining ground against such 'cartel' systems around Europe, and they are doing so not only in cases where economic hardship has hit hard, but also in cases where the economy has performed rather well and institutions are stable and efficient. 
In the South, the populist Left has found a favourable environment to put forth demands against austerity, rising inequality and impoverishment, in favour of reincluding the marginalised social strata. In the North, the populist Right has managed to attract voters that were frustrated with mainstream parties, channelling social anxieties through identity issues, stressing the need to return to strong nation-states that provide welfare to 'their own.' In most cases, it would be impossible for such parties to succeed, if this 'gap of representation' wasn't there for them to fill; if a latent crisis of representation hadn't already challenged existing identities, political commitments and established social compromises.

To sum up, any discussion regarding the 'populist challenge' for today's Europe and Western democracies in general cannot be productive if we don't take into account the inherent ambiguity of the phenomenon: both threat and corrective, both fulfilling a democratising promise and susceptible to authoritarian turns, both progressive and regressive. The a priori demonization of populism that ignores its specific content and message, is doomed to backfire, since along with dismissing the populist 'devils,' one risks dismissing 'the people' themselves, their worries, frustrations and grievances. Unfortunately, this is the path that has too often been chosen by mainstream political forces and intellectuals around Europe, quite characteristically in France, leading to a paradoxical self-fulfilling prophecy: by denouncing any opposition to the mainstream, by dismissing any critique to the 'moderate' forces as 'dangerous populism,' its leadership has been feeding anti-establishment actors which now take a firm reactionary stance and seem more powerful than ever. Marine Le Pen's performance in recent elections is a bitter reminder of such a dynamic. 
What is worse, being unable to distinguish between populists of different kinds and orientations, this kind of mainstream 'anti-populist' discourse has often lumped together extremely different political actors (e.g. Podemos with the FN), failing to establish ideologico-political exchanges that could be productive both for democracies on the national level and also for the development and further democratisation of the EU itself. Crucially, and very tellingly, European elites have appeared more willing to tolerate forces on the right, like Orbán, who is alarmingly anti-liberal and authoritarian, than others on the left, as exemplified by the brutal stance of European elites against the SYRIZA-led government. Moreover, traditional parties around Europe have accompanied their public critique against 'populists' with the actual endorsement of policies advocated by the populist extreme-right, as it is the case, again, in France, where both the centre-right and the centre-left have adopted elements of the FN's discourse and policies on immigration and security.

However, risky and heretical as it may sound, mainstream parties ought to take seriously the demands of populists on the various issues which they raise, from participatory democracy to transparency, and from wealth distribution and social protection to popular accountability. And they do not just have to take them into account, but they ought to respond to them with concrete policy proposals and with discourses that can aspire positive passions of hope among the citizens that struggle in conditions of stagnation and generalised impasse. After all, this is the main reason why populists are so successful: they represent certain salient societal issues against which traditional parties have remained unresponsive or even hostile. 
The coming months will probably provide even more occasions to further reflect on the relation between unresponsive elites implementing unpopular policies and the rise of populist challengers. If my analysis has some validity, then I wouldn't be surprised to see populist actors doing well in forthcoming elections in countries like France, Austria and Germany. The crucial issue though has to do with the kind of demands that such populists will put forth. My suspicion is that, after crushing a left-wing alternative (namely SYRIZA), EU's key political actors have created an environment more conductive to the rise of right-wing populism. But that, of course, is rather speculation. We will have to wait and see.

\section{Acknowledgment}

I would like to thank the Research Committee of the Aristotle University of Thessaloniki for its support through the 'Excellence Scholarship' for postdoctoral researchers.

${ }^{1}$ J.W. Müller, What is Populism?, Pennsylvania, University of Pennsylvania Press, 2016.

${ }^{2}$ A. Mondon, A Populist Hegemony? The mainstreaming of the extreme right in France and Australia, Farnham, Ashgate, 2013.

${ }^{3}$ C. Mudde, Populist Radical Right Parties in Europe, Cambridge, Cambridge University Press, 2007.

${ }^{4}$ G. Katsambekis, 'Radical Left Populism in Contemporary Greece: Syriza's Trajectory from Minoritarian Opposition to Power,' Constellations, vol. 23, no. 3, 2016, pp. 391-403; A. Kioupkiolis, 'Podemos: the ambiguous promises of left-wing populism in contemporary Spain,' Journal of Political Ideologies, vol. 21, no. 2, 2016, pp. 99-120.

${ }^{5}$ See the relevant work done within the context of the POPULISMUS project: www.populismus.gr.

${ }^{6}$ E. Laclau, Politics and Ideology in Marxist Theory: Capitalism, Fascism, Populism, London, NLB, 1977; E. Laclau, On populist reason, London, Verso, 2005. 
${ }^{7}$ See F. Panizza (ed.), Populism and the Mirror of Democracy, London, Verso, 2005; Y. Stavrakakis \& G. Katsambekis, 'Left-wing Populism in the European Periphery: The Case of Syriza,' Journal of Political Ideologies, vol. 19, no. 2, 2014, pp. 119-142.

${ }^{8}$ P. Taggart, Populism, Buckingham, Open University Press, 2000.

${ }^{9}$ C. de la Torre (ed.), The Promise and Perils of Populism, Lexington, University Press of Kentucky, 2014; B. Moffitt, The Global Rise of Populism, California, Stanford University Press, 2016.

${ }^{10}$ K. Roberts, 'Populism, Political Mobilizations, and Crises of Political Representation,' in C. de la Torre (ed.) The Promise and Perils of Populism, Lexington, The University Press of Kentucky, 2015, pp. $140-158$.

${ }^{11}$ C. Mouffe, Agonistics: Thinking the World Politically, London, Verso, 2013; C. Crouch, 'The March Towards Post-Democracy,' The Political Quarterly, vol. 87, no. 1, 2016, pp. 71-75.

${ }^{12}$ P. Mair, Ruling the Void: The Hollowing-out of Western Democracy, London, Verso, 2013. 